\title{
PENGARUH KREATIVITAS, KOMUNIKASI, DAN KEPEMIMPINAN GURU TERHADAP PRESTASI BELAJAR SISWA PADA SMP NEGERI DI KECAMATAN ILIR TIMUR II PALEMBANG
}

\author{
Oleh: \\ Sindang Sari dan Omar Hendro \\ Mahasiswa Pascasarjana UMP dan Dosen Pascasarjana UMP Palembang \\ Email : Sindang1110@yahoo.com dan Omarhendro@ymail.com
}

\begin{abstract}
Abstraksi
Kegiatan yang dilakukan untuk memperoleh (1) Mempengaruhi kreativitas, komunikasi, dan kepemimpinan guru secara bersamaan terhadap prestasi siswa di Sekolah Menengah Atas Negeri di Kecamatan Ilir Timur I Palembang, dan (2) Mempengaruhi kreativitas, komunikasi, dan kepemimpinan guru secara parsial terhadap prestasi belajar siswa Sekolah Menengah Atas Negeri di Kecamatan Ilir Timur I Palembang. Desain yang digunakan dalam penelitian ini adalah penelitian yang dilakukan. Ada empat variabel. Itu adalah variabel bebas yang Kreativitas Guru (X1), Komunikasi Guru (X2) dan Kepemimpinan Guru (X3), dan juga variabel dependen yang menjadi Prestasi Siswa (Y). Metode pengambilan sampel yang digunakan adalah metode Cutter, Proporsional, Purposive Random Sampling. Sampel yang digunakan dalam penelitian ini adalah 98 siswa. Untuk mengukur pengaruh antar variabel, digunakan regresi linier berganda, untuk menguji hipotesis yang digunakan adalah hipotesis $\mathrm{F}$ dan uji hipotesis. Berdasarkan hasil analisis regresi, diperoleh bahwa: (1) Secara simultan variabel aktivitas, komunikasi, dan kepemimpinan guru tidak berpengaruh signifikan terhadap Prestasi Siswa, (2) Secara parsial, variabel aktivitas guru, komunikasi, dan kepemimpinan tidak berpengaruh signifikan terhadap Prestasi Siswa.
\end{abstract}

Kata kunci: Kreativitas, Komunikasi, Kepemimpinan, dan Prestasi.

\section{PENDAHULUAN}

Hakekat belajar adalah suatu proses yang ditandai dengan adanya perubahan pada diri seorang siswa. Perubahan sebagai hasil proses belajar dapat ditunjukkan dengan berbagai bentuk seperti berubahnya pengetahuan, pemahaman, sikap dan tingkah laku, keterampilan, kecakapan, kemampuan, dan aspek-aspek lain yang ada pada diri siswa tersebut.Prestasi belajar dan proses belajar adalah satu kesatuan yang tidak dapat dipisahkan. Karena prestasi belajar pada hakikatnya adalah hasil akhir dari sebuh proses belajar. Untuk mengetahui prestasi belajar seorang siswa biasanya dilakukan evaluasi terhadap materi belajar yang telah diberikan. Seberapa besar siswa mampu memberikan feed back dari setiap evaluasi yang diberikan, demikianlah gambaran prestasi belajar yang dimilikinya.

Prestasi belajar siswa bukanlah barang yang mutlak, karena terlebih dahulu siswa harus belajar yang aktif untuk mencapai kualitas yang baik. Oleh karena itu, guru harus terlebih dahulu berperan banyak di dalam meningkatkan prestasi belajar siswanya.

Menurut Winkel (2009: 122), prestasi belajar merupakan salah satu bukti yang menunjukkan kemampuan atau keberhasilan seseorang yang melakukan proses belajar sesuai dengan bobot atau nilai yang berhasil diraihnya. Sedangkan menurut Surya (2009: 75), prestasi belajar adalah hasil belajar atau perubahan tingkah laku yang menyangkut ilmu pengetahuan, keterampilan dan sikap setelah melalui 
proses tertentu, sebagai hasil pengalaman individu dalam interaksi dengan lingkungannya.

Prestasi belajar siswa merupakan unsur dasar yang penting bagi keberhasilan proses pembelajaran. Keaktifan siswa dalam proses pembelajaran dapat merangsang dan mengembangkan bakat yang dimilikinya, siswa juga dapat berlatih untuk berfikir kritis, dan dapat memecahkan permasalahan-permasalahan dalam kehidupan sehari-hari. Menurut Idochi (2010: 288), upaya yang dapat dilakukan guru untuk meningkatkan prestasi belajar anak didiknya, adalah melakukan proses pembelajaran dengan metode yang lebih kreatif, menyampaikan materi pembelajaran secara baik, dan dapat mengayomi (memimpin) anak didiknya, baik di dalam kelas maupun di luar kelas.

Untuk mencapai prestasi belajar siswa, dituntut peran guru yang kreatif. Guru yang kreatif menggunakan segala sesuatu yang dimilikinya untuk mengaktualisasikan pembelajaran aktif guna memotivasi siswa, seperti pemikiran, fakta, dan ide-ide atau bahkan kombinasi pemikiran, fakta dan ide-ide. Guru yang kreatif mampu melakukan proses pembelajaran secara efektif dengan menggabungkan berbagai kontekstual instruksional bahan, strategi pengajaran, pembelajaran media dan pengalaman kehidupan nyata.

Guru yang kreatif berusaha untuk menyediakan sebanyak mungkin ruang bagi siswa dalam proses pembelajaran. Proses pembelajaran diselenggarakan secara interaktif, inspiratif, menyenangkan, menantang dan memotivasi siswa untuk kreatif dan berpartisipasi aktif, serta memberikan ruang yang cukup bagi prakarsa, Kreatifitas, dan kemandirian sesuai dengan bakat, minat, dan perkembangan fisik serta psikologis siswa (Peraturan Pemerintah Nomor 19 Tahun 2005 tentang Standar Nasional Pendidikan). Mempertimbangkan standar proses pembelajaran seperti yang tertuang dalam Peraturan Pemerintah tersebut maka guru sebagai ujung tombak pendidikan dituntut untuk lebih kreatif, mampu menciptakan pembelajaran yang menggairahkan, berkualitas, dan menyenangkan. Selain kreatifitas, kemampuan guru dalam berkomunikasi (terutama dalam proses pembelajaran) dengan siswa-siswanya juga menjadi faktor penentu di dalam meningkatkan prestasi belajar siswa, karena dengan komunikasi yang dapat dimengerti oleh siswa, maka akan mempermudah bagi siswa yang bersangkutan untuk memahami pelajaran yang disampaikan oleh gurunya. Kemampuan berkomunikasi guru sangatlah penting karena dengan komunikasi yang baik, maka pesan-pesan yang disampaikan dapat diterima dengan baik pula, sehingga apa yang menjadi tujuan akan dapat tercapai. Kemampuan berkomunikasi guru adalah kemampuan guru dalam menciptakan iklim komunikatif antara guru dengan siswa dalam proses pembelajaran.

Pembelajaran merupakan interaksi dua arah dari seorang guru dan siswa, di mana antara keduanya terjadi komunikasi (transfer) yang intens dan terarah menuju pada suatu target (tujuan) yang telah ditetapkan sebelumnya Pembelajaran bukan hanya proses mentransfer ilmu pengetahuan, namun juga untuk membentuk watak, sikap moral dan pola pikir (Ahmadi, 2010: 3).

Keberhasilan komunikasi guru dalam proses pembelajaran merupakan aset penting bagi pencapaian sasaran atau tujuan pendidikan, keberhasilan tersebut tercermin pada prestasi belajar yang dicapai siswa. Melalui proses komunikasi antara guru dan siswa dimungkinkan terjadinya pertukaran informasi sehingga siswa dapat menguasai materi yang dipelajari. Bila komunikasi yang dilakukan oleh guru hanya satu arah, maka sering siswa kurang berminat terhadap pelajaran yang akan disampaikan oleh guru. Hal ini dapat dilihat dari sikap siswa dalam menerima pelajaran. Beberapa diantaranya adalah kebiasaan siswa yang berbicara 
dengan teman sebelahnya pada saat guru sedang menyampaikan pelajaran, siswa mengantuk, atau siswa yang sibuk sendiri dengan mencorat-coret buku.

Kepemimpinan guru dalam pembelajaran di kelas bisa bersumber dari kekuasaan memaksa, legitimasi, keahlian, penghargaan, relevansi, informasi, atau hubungan (Toha, 2009: 323). Guru mempunyai kekuasan memaksa di kelas karena dilihat dari usia dan kematangan, guru biasanya relatif lebih tua dibanding siswanya. Gurupun tentu punya legitimasi, karena ditunjuk sekolah untuk mengajar di kelas, mempunyai keahlian dan informasi yang dibutuhkan siswa, karena guru dididik untuk keperluan itu. Kekuasaan yang bersumber pada penghargaan dan hubungan bisa juga dimiliki guru, karena ini memiliki kedudukan yang luhur, sehingga patut digugu dan ditiru.

Dalam kurikulum 2013, siswa dituntut lebih aktif dalam belajar, dimana hal ini bertujuan untuk membentuk karakter berfikir kritis, kreatif, dan mandiri. Kurikulum 2013 menuntut adanya pola pikir guru yang dirubah, bahwa proses pembelajaran bukan hanya dari guru, namun bagaimana agar ada keinginan dalam mencari ilmu berasal dari murid. Siswa harus lebih aktif bertanya kepada guru, dan siswa harus juga bisa mencari referensi atau contoh soal di internet dan belajar di rumah. Karena itu guru harus mampu melaksanakan proses belajar mengajar sesuai dengan tema yang dikaitkan dengan kondisi nyata siswa, berpusat pada siswa, dan siswa dituntut aktif dalam pembelajaran (Peraturan Menteri Pendidikan dan Kebudayaan, 2013).

Pengamatan awal yang dilakukan terhadap SMP Negeri No. 4, SMP Negeri No. 8, SMP Negeri No.42 dan SMP Negeri No.50 di Kecamatan Ilir Timur II Palembang, peneliti mendapatkan gambaran bahwa kreatifitas guru, komunikasi guru, dan kepemimpinan guru belum berjalan seperti yang diharapkan, sehingga prestasi belajar siswa di kedua
SMP tersebut juga masih kurang baik. Salah satu tolok ukur yang digunakan untuk mengetahui prestasi belajar siswa, mulai siswa SD, SMP, maupun SMA, adalah Kriteria Ketuntasan Minimal (KKM). KKM adalah patokan nilai terendah dalam penilaian siswa. Jika siswa mampu mendapatkan nilai di atas KKM, maka dianggap siswa tersebut telah tuntas atau menguasai kompetensi yang dipelajari. Sebaliknya jika ditemukan siswa mendapat nilai di bawah KKM berarti perlu adanya perbaikan.

Tabel 1

Nilai KKM di SMP Negeri di Kecamatan Ilir Timur II Kota Palembang

\begin{tabular}{|c|l|c|c|}
\hline No. & $\begin{array}{c}\text { Nama } \\
\text { Sekolah }\end{array}$ & $\begin{array}{c}\text { Nilai } \\
\text { KKM }\end{array}$ & $\begin{array}{c}\text { Nilai KKM yang } \\
\text { diterapkan saat ini }\end{array}$ \\
\hline 1. & SMP Negeri 4 & $75-80$ & $75-80$ \\
\hline 2. & SMP Negeri 8 & $1-4$ & 2,67 \\
\hline 3. & SMP Negeri 42 & $70-80$ & $70-80$ dan 2,67 \\
\hline 4. & SMP Negeri 50 & $75-80$ & $75-80$ \\
\hline
\end{tabular}

Sumber: SMP Negeri di Kec. IT II Kota Palembang,2014

Berdasarkan Tabel I, peneliti mendapatkan gambaran bahwa prestasi belajar siswa masih berada pada rata-rata KKM. Hanya sebagian kecil siswa yang memperoleh nilai di atas rata-rata. Selain itu di antara siswa di SMP Negeri tersebut, kurang terjalin kerjasama yang baik, sehingga menyebabkan perbedaan prestasi belajar yang cukup jauh antar siswa, siswa cenderung pasif, hanya menerima saja apa yang disampaikan guru, kurangnya kemampuan siswa dalam menguasai materi pelajaran yang disampaikan guru, hal ini terlihat pada saat guru bertanya kepada siswa terkait dengan materi disampaikan, hanya 5-10 siswa yang mampu menjawab dari rata-rata 40 siswa dalam 1 (satu) kelas.

Siswa-siswa juga kurang bersemangat dalam pelajaran yang diikutinya, tidak merasa tertantang di dalam mengikuti mata pelajaran, sulit untuk memahami apa yang disampaikan oleh guru, kurang berminat di dalam mengikuti pelajaran, tidak sedikit justru siswa berbicara dengan sesama temannya, sibuk mencoret-coret bukunya, dan ironinya ada diantara siswa tersebut 
malah mengantuk, dan siswa tidak begitu segan dengan guru-gurunya.

Kreativitas guru juga masih kurang optimal, hal ini terlihat dari guru yang jarang menggunakan alat bantu pembelajaran seperti gambar (picture to picture) untuk mata pelajaran yang harus menggunakan alat peraga, seperti mata pelajaran IPA. Selain itu, karena mata pelajaran yang terpadu, guru hanya terfokus pada buku yang tersedia, guru tidak memiliki strategi khusus untuk meningkatkan kualitas siswa-siswanya, serta guru tidak memberikan kesempatan kepada siswa-siswanya untuk berpartisipasi terhadap pelajaran. Guru masih ada yang menggunakan metode pembelajaran ceramah, belum menerapkan metode pembelajaran yang lebih kreatif, kurang mampu memotivasi siswasiswanya untuk berpartisipasi aktif dalam belajar, kurang memberikan kesempatan kepada siswa-siswanya untuk berinspirasi terhadap mata pelajaran yang diikutinya.

Kemampuan komunikasi guru masih kurang baik, hal ini terlihat dari kurangnya interaksi antara guru dengan siswa, dan antara siswa dengan siswa, guru hanya menjelaskan sedikit tentang materi pembelajaran lalu aktivitas kelas diserahkan kepada siswa, komunikasi yang dilakukan sifatnya masih satu arah, serta guru masih belum mampu mengajak siswa untuk berdiskusi atas mata pelajaran yang disampainya. Pada saat menyampaikan materi pelajaran, guru belum menggunakan alat bantu in focus atau komputer untuk membantu menyampaikan materi pelajaran dengan lebih menarik.

Kepemimpinan guru juga masih belum maksimal, hal ini terlihat dari guru yang terfokus pada diri sendiri dalam proses pembelajaran, sehingga siswa-siswa menjadi ribut di dalam kelas, guru kurang tegas menghadapi siswa yang ribut. Setelah menjelaskan sedikit tentang materi pelajaran, masih ada guru yang meninggalkan kelas, sehingga ada siswa yang keluar masuk pada saat jam pelajaran berlangsung. Siswa sering ditinggal karena ada guru yang harus mengikuti pelatihan, yang mana guru tersebut digantikan oleh mahasiswa magang (PKL) selama beberapa waktu. Masih ada guru, belum mampu memimpin siswa-siswanya dalam belajar, guru terkesan membiarkan saja siswanya belajar sendiri di dalam kelas, guru tidak berusaha untuk membangun semangat belajar yang baik kepada siswasiswanya.

\section{RUMUSAN MASALAH}

Rumusan masalah dalam penelitian ini adalah adakah pengaruh kreatifitas, komunikasi, dan kepemimpinan guru secara simultan dan secara parsial terhadap prestasi belajar siswa pada SMP Negeri di Kecamatan Ilir Timur II Palembang.

\section{TUJUAN PENELITIAN}

Untuk mengetahui pengaruh kreatifitas, komunikasi, dan kepemimpinan guru secara simultan dan secara parsial terhadap prestasi belajar siswa pada SMP Negeri di Kecamatan Ilir Timur II Palembang.

\section{TINJAUAN PUSTAKA}

\section{Prestasi Belajar}

Menurut Winkel (2009: 122), prestasi belajar merupakan salah satu bukti yang menunjukkan kemampuan atau keberhasilan seseorang yang melakukan proses belajar sesuai dengan bobot atau nilai yang berhasil diraihnya.

Menurut Surya (2009: 75), prestasi belajar adalah hasil belajar atau perubahan tingkah laku yang menyangkut ilmu pengetahuan, keterampilan dan sikap setelah melalui proses tertentu, sebagai hasil pengalaman individu dalam interaksi dengan lingkungannya.

\section{Kreativitas Guru}

Menurut Soekartini (2009: 32), kreatifitas guru adalah guru yang mampu mengaktualisasikan dan mengekspresikan secara optimal segala kemampuan yang ia miliki dalam rangka membina dan mendidik dengan baik. Seorang guru yang kreatif akan memiliki sikap kepekaan, 
inisiatif, cara baru dalam mengajar, kepemimpinan serta tanggungjawab yang tinggi dalam pekerjaan dan tugasnya sebagai seorang pendidik.Menurut Clark (dalam Utami, 2012: 24), kreatifitas adalah pengalaman mengekspresikan identitas individu dalam bentuk terpadu dalam hubungan dengan diri sendiri, dengan alam dan orang lain. Menurut Slameto (2010: 77), kreatif berhubungan dengan penemuan sesuatu, mengenai hal yang menghasilkan sesuatu yang baru dengan menggunakan sesuatu yang telah ada.

\section{Komunikasi Guru}

Menurut Ruky (2010: 191), komunikasi adalah transimisi informasi, gagasan, emosi, ketrampilan dan sebagainya, dengan menggunakan simbolsimbol; kata-kata, gambar, figur, grafik, dan sebagainya. Tindakan atau proses transmisi itulah yang biasanya disebut komunikasi. Menurut Mangkunegara (2010: 76), komunikasi adalah proses yang memungkinkan seseorang (komunikator) menyampai-kan rangsangan (biasanya lambang-lambang verbal) untuk merubah perilaku orang lain (komikate).

\section{Kepemimpinan Guru}

Menurut Idochi (2010: 288), kepemimpinan guru adalah kemampuan seorang guru dalam mempengaruhi siswanya, sehingga siswa tersebut bertingkah-laku sebagaimana dikehendaki oleh guru tersebut. Menurut Purbakawaca (2009: 128), kepemimpinan guru adalah suatu kesiapan, kemampuan yang dimiliki oleh seorang guru dalam proses mempengaruhi, mendorong, membimbing, mengarahkan dan menggerakkan siswanya yang ada hubungannya dengan pelaksanaan dan pengembangan proses pembelajaran, agar segenap kegiatan dapat berjalan secara efektif dan efisien dalam mencapai tujuan pembelajaran.

\section{OPERASIONALISASI VARIABEL}

Operasional variabel dalam penelitian ini terdiri atas variabel tidak bebas (dependent) adalah prestasi belajar (Y), sedangkan variabel bebas (independent) terdiri dari kreativitas (X1), komunikasi (X2), dan kepemimpinan (X3).

\section{POPULASI DAN SAMPEL}

Populasi seluruh siswa-siswi yang bersekolah di SMP Negeri di Kecamatan Ilir Timur II Palembang, yang terdiri dari SMP Negeri 4 Palembang sebanyak 952 orang siswa; SMP Negeri 8 Palembang sebanyak 930 orang siswa; SMP Negeri 42 Palembang sebanyak 703 orang siswa; dan SMP Negeri 50 Palembang sebanyak 1.032 orang, sehingga populasi yang digunakan dalam penelitian ini yaitu sebanyak 3.617 orang siswa. Sampel yang diambil dari populasi siswa-siswi yang bersekolah pada SMP Negeri di Kecamatan Ilir Timur II Palembang dengan menggunakan rumus Slovin adalah sebagai berikut:

$$
\begin{aligned}
& n=\frac{3.617}{1+3.617(0,10)^{2}} \\
& n=97,31(98 \text { responden })
\end{aligned}
$$

Sampel yang dipakai sebanyak 98 orang, untuk masing-masing sekolah jumlah sampel disebar berdasarkan alokasi sampel proporsional sebagai berikut pada Tabel 2.

Tabel 2

Jumlah Siswa-Siswi SMP Negeri

\begin{tabular}{|c|c|c|c|c|c|}
\hline No. & $\begin{array}{c}\text { Nama } \\
\text { Sekolah }\end{array}$ & $\begin{array}{c}\text { Jml } \\
\text { Siswa }\end{array}$ & Persentase & $\begin{array}{c}\text { Jml } \\
\text { Sampel }\end{array}$ & $\begin{array}{l}\text { Alokasi } \\
\text { Sampel }\end{array}$ \\
\hline 1. & SMP Negeri 4 & 952 & $26,32 \%$ & \multirow{4}{*}{98} & 26 \\
\hline 2. & SMP Negeri 8 & 930 & $25,71 \%$ & & 25 \\
\hline 3. & SMP Negeri 42 & 703 & $19,44 \%$ & & 19 \\
\hline 4. & SMP Negeri 50 & 1.032 & $28,53 \%$ & & 28 \\
\hline & Jumlah & 3617 & $100,00 \%$ & & 98 \\
\hline
\end{tabular}

di Kecamatan Ilir Timur II Palembang

Sumber: SMPN di Kec. Ilir Timur II Palembang,

2014

\section{HASIL PENELITIAN DAN PEMBAHASAN}

\section{Hasil Penelitian}

1) Uji Regresi Berganda

Untuk menjawab bagaimana pengaruh Kreativitas $\left(\mathrm{X}_{1}\right)$, Komunikasi $\left(\mathrm{X}_{2}\right)$ dan Kepemimpinan $\left(\mathrm{X}_{3}\right)$ secara parsial terhadap prestasi belajar (Y), diperoleh hasil untuk regresi berganda dengan persamaan sebagai berikut: 


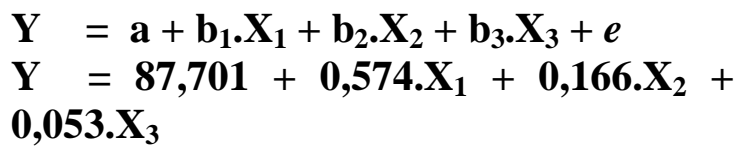

Berdasarkan hasil estimasi yang terbentuk dalam sebuah persamaan di atas dapat interpretasikan, yaitu: nilai konstanta (a) sebesar 87,701; artinya apabila variabel Kreatifitas Guru $\left(\mathrm{X}_{1}\right)$, Komunikasi Guru $\left(\mathrm{X}_{2}\right)$, dan Kepemimpinan Guru $\left(\mathrm{X}_{3}\right)$ sama dengan $0\left(X_{1}, X_{2}\right.$, dan $\left.X_{3}=0\right)$, maka Prestasi Belajar Siswa (Y)SMP Negeri di Kecamatan Ilir Timur II Palembang adalah tetap sebesar 87,701.

Nilai koefisien regresi variabel Kreatifitas Guru $\left(\mathrm{X}_{1}\right)$ adalah sebesar 0,574 $(57,4 \%)$; artinya bahwa kontribusi Kreatifitas Guru $\left(\mathrm{X}_{1}\right)$ terhadap Prestasi Belajar Siswa (Y) adalah sebesar 57,4\%.Nilai koefisien regresi variabel Komunikasi Guru $\left(\mathrm{X}_{2}\right)$ adalah sebesar 0,166 (16,6\%); artinya bahwa kontribusi Komunikasi Guru $\left(\mathrm{X}_{2}\right)$ terhadap Prestasi Belajar Siswa (Y) adalah sebesar 16,6\%. Nilai koefisien regresi variabel Kepemimpinan Guru $\left(\mathrm{X}_{3}\right)$ adalah sebesar $0,053(5,3 \%)$; artinya bahwa kontribusi Kepemimpinan Guru $\left(\mathrm{X}_{3}\right)$ terhadap Prestasi Belajar Siswa (Y) adalah sebesar $5,3 \%$.

Hasil model analisis tersebut, koefisien regresi terbesar adalah pada variabel Kreatifitas Guru $\left(\mathrm{X}_{1}\right)$ atau dengan kata lain bahwa faktor yang paling dominan pengaruhnya terhadap Prestasi Belajar Siswa pada SMP Negeri di Kecamatan Ilir Timur II Palembang adalah Kreatifitas Guru, sehingga semakin tinggi Kreatifitas Guru, maka Prestasi Belajar Siswa juga akan meningkat, sebaliknya semakin rendah Kreatifitas Guru, maka Prestasi Belajar Siswa juga akan menurun.

\section{2) Uji Koefisien Determinan}

\section{Pengaruh Kreativitas}

$\left(\mathrm{X}_{1}\right)$,

Komunikasi $\left(\mathrm{X}_{2}\right)$, dan Kepemimpinan $\left(\mathrm{X}_{3}\right)$ guru secara bersama-sama terhadap prestasi Belajar (Y) siswa, yaitu dengan menggunakan uji Koefisien Determinan dengan nilai $R$ Square adalah sebesar
0,259 (25,9\%); angka tersebut berarti bahwa Prestasi Belajar Siswa (Y) pada SMP Negeri di Kecamatan Ilir Timur II Palembang, dapat dijelaskan oleh Kreatifitas Guru $\left(\mathrm{X}_{1}\right)$, Komunikasi Guru $\left(\mathrm{X}_{2}\right)$, dan Kepemimpinan Guru $\left(\mathrm{X}_{3}\right)$ sebesar 25,9\%; sedangkan selebihnya sebesar $74,1 \%$ dijelaskan oleh faktor lain yang tidak masuk dalam penelitian ini, seperti misalnya metode pembelajaran yang digunakan, fasilitas pembelajaran, ruang kelas yang kondusif, keaktifan belajar siswa, dukungan dari orang tua dan keluarga, fasilitas yang diberikan oleh orang tua, tingkat penghasilan orang tua, tingkat pendidikan orang tua, dan masih banyak faktor-faktor lainnya.

\section{3) Uji Hipotesis}

a. Uji F ( Uji bersama-sama)

Untuk menjawab permasalahan tentang bagaimana pengaruh Kreativitas $\left(\mathrm{X}_{1}\right), \quad$ Komunikasi $\left(\mathrm{X}_{2}\right), \quad$ dan Kepemimpinan $\left(\mathrm{X}_{3}\right)$ guru secara bersamasama terhadap prestasi Belajar (Y) siswa, nilai F-hitung sebesar 0,632. Sedangkan Ftabel dengan taraf nyata $(\alpha)=5 \%$ dengan penyebut $(\mathrm{n}-\mathrm{k}-1)=(98-3-1)=94$; dan pembilang $(\mathrm{k}=3)$ adalah sebesar $\mathbf{+ 2 , 7 0 0}$. Nilai F-hitung $(0,632)<$ F-tabel $(2,700)$, sedangkan nilai signifikan (Sig F) yaitu sebesar $(0,596)>\alpha(0,05)$, hal tersebut berarti bahwa Ho diterima dan Ha ditolak, sehingga tidak ada pengaruh yang signifikan Kreatifitas, Komunikasi, dan Kepemimpinan Guru secara simultan terhadap Prestasi Belajar Siswa pada SMP Negeri di Kecamatan Ilir Timur II Palembang.

b. Uji t (Uji parsial)

Untuk menjawab permasalahan tentang bagaimana pengaruh Kreativitas $\left(\mathrm{X}_{1}\right), \quad$ Komunikasi $\left(\mathrm{X}_{2}\right), \quad$ dan Kepemimpinan $\left(\mathrm{X}_{3}\right)$ guru secara parsial terhadap prestasi Belajar (Y) siswa, sebagai berikut:

Berdasarkan pada persamaan regresi berganda diatas didapat nilai t-hitung Kreatifitas Guru $\left(\mathrm{X}_{1}\right)$ sebesar 1,339; nilai t-hitung Komunikasi Guru $\left(\mathrm{X}_{2}\right)$ sebesar 
0,548; dan nilai t-hitung Kepemimpinan Guru $\left(\mathrm{X}_{3}\right)$ adalah sebesar 0,130. Sedangkan nilai t-tabel dengan taraf nyata $(\alpha)=5 \%$, dan nilai df $(n-2)=(98-2)=96$, sebesar $\pm \mathbf{1 , 9 8 6}$.

Sehingga nilai t-hitung Kreatifitas Guru $\left(\mathrm{X}_{1}\right)$ sebesar $(1,339)<\mathrm{t}$-tabel $(1,986)$. Sedangkan nilai signifikan (Sig t) adalah $(0,184)>\alpha(0,05)$, hal tersebut berarti bahwa Ho diterima dan Ha ditolak.

Nilai t-hitung Komunikasi Guru $\left(\mathrm{X}_{2}\right)$ adalah sebesar $(0,548)<\mathrm{t}$-tabel $(1,986)$. Sedangkan nilai signifikan ( Sig t) adalah $(0,585)>\alpha(0,05)$, hal tersebut berarti bahwa Ho diterima dan Ha ditolak.

Nilai t-hitung Kepemimpinan Guru $\left(\mathrm{X}_{3}\right)$ adalah sebesar $(0,130)<\mathrm{t}$-tabel $(1,986)$. Sedangkan nilai signifikan (Sig t) adalah $(0,897)>\alpha(0,05)$, hal tersebut berarti Ho diterima dan $\mathrm{Ha}$ ditolak, sehingga tidak ada pengaruh yang signifikan Kreatifitas, Komunikasi, dan Kepemimpinan, Guru secara parsial terhadap Prestasi Belajar Siswa pada SMP Negeri di Kecamatan Ilir Timur II Palembang.

\section{Pembahasan Hasil Penelitian}

1). Pengaruh Kreatifitas, Komunikasi, dan Kepemimpinan Guru secara bersama-sama terhadap Prestasi Belajar Siswa pada SMP Negeri di Kecamatan Ilir Timur II Palembang

Hasil pengujian koefisien determinasi, menjelaskan bahwa variabel Kreatifitas, Komunikasi, dan Kepemimpinan Guru dapat menjelaskan Prestasi Belajar Siswa pada SMP Negeri di Kecamatan Ilir Timur II Palembang hanya sebesar 25,9\%, sedangkan selebihnya sebesar $74,1 \%$ dijelaskan oleh faktor lain yang tidak masuk dalam penelitian ini, seperti misalnya metode pembelajaran yang digunakan, fasilitas pembelajaran, ruang kelas yang kondusif, keaktifan belajar siswa, dukungan dari orang tua dan keluarga, fasilitas yang diberikan oleh orang tua, tingkat penghasilan orang tua, tingkat pendidikan orang tua, dan masih banyak faktor-faktor lainnya, dan berdasarkan hasil uji hipotesis $\mathrm{F}$, dapat dijelaskan bahwa tidak ada pengaruh yang signifikan variabel Kreatifitas, Komunikasi, dan Kepemimpinan Guru terhadap Prestasi Belajar Siswa pada SMP Negeri di Kecamatan Ilir Timur II Palembang.

Jika dibandingkan dengan beberapa penelitian sebelumnya, bahwa penelitian yang peneliti lakukan ada yang berbeda dan ada yang mendukung, seperti pada penelitian yang dilakukan oleh Septi (2011), yang mendapatkan hasil bahwa terdapat pengaruh positif dan signifikan kreativitas mengajar guru terhadap prestasi belajar. Sedangkan penelitian yang dilakukan oleh Dwi (2012), mendapatkan hasil bahwa tidak ada pengaruh kreatifitas guru terhadap prestasi belajar siswa, begitu pula dengan penelitian Marimin dan Dian (2013), mendapatkan hasil bahwa pengaruh variabel kepemimpinan terhadap motivasi belajar siswa hanya sebesar $14,62 \%$, dan pengaruh kemampuan berkomunikasi guru terhadap motivasi belajar siswa hanya sebesar $17,52 \%$.

Hal ini menjelaskan bahwa kreativitas guru, komunikasi, dan kepemimpinan tidak dapat menjadi alat untuk dapat meningkat prestasi belajar siswa. Apalagi jika dikaitkan dengan kurikulum yang diterapkan sekarang yaitu Kurikulum 2013, ternyata dianggap belum saatnya dilakukan, karena penerapannya tidak dibarengi dengan kesiapan infrastruktur dan sumber daya manusianya.

Hal ini menjadi indikasi bahwa guruguru di pada SMP Negeri di Kecamatan Ilir Timur II Palembang belum benarbenar memahami tema pelajaran pada Kurikulum 2013 tersebut, sehingga kreativitas yang dibangun oleh guru masih "meraba-raba", bahkan banyak guru yang menggunakan persepsi mereka sendiri dalam memahami tema pelajaran, karena keterbatasan itulah yang mengakibatkan kurangnya daya serap siswa terhadap tema pelajaran yang disampaikan oleh guru. Kurikulum 2013 mengharuskan siswa 
harus lebih aktif, dan kreatif daripada guru. Hal ini mengakibatkan siswa merasa tanpa kreatifitas yang cukup dari guru, siswa akan tetap menjadi pihak yang lebih 'direpotkan' daripada guru, yang pada gilirannya mengakibatkan prestasi belajar siswa pada SMP Negeri di Kecamatan Ilir Timur II Palembang jadi menurun.

Begitu pula dengan komunikasi guru, terutama komunikasi vertikal antara guru dengan siswa tidak memberikan pengaruh yang signifikan terhadap prestasi belajar siswa pada SMP Negeri di Kecamatan Ilir Timur II Palembang, ternyata bukan pola komunikasinya yang salah, namun pemahaman guru terhadap tema pelajaran pada Kurikulum 2013 yang masih kurang. Sehingga guru masih bingung cara menyampaikan dan membahas tema pelajaran tersebut, seolah-olah terkesan guru-guru pada SMP Negeri di Kecamatan Ilir Timur II Palembang tidak mampu berkomunikasi dengan siswa-siswinya, padahal guru-guru tersebut sebenarnya belum mampu menyampaikan tema pelajarannya, serta belum menemukan pola komunikasi yang tepat untuk menyampaikan tema pelajaran tersebut. Selain itu dalam Kurikulum 2013 proses pembelajaran setiap tema dilakukan dengan pendekatan ilmiah, dimana siswa mencari tahu sendiri dalam pembelajaran, dengan mengamati, menanya, mengolah, menyajikan, menyimpulkan dan mencipta. Hal ini menyebabkan guru menekankan siswa yang harus lebih aktif dalam proses pembelajaran, sehingga guru hanya menyampaikan hal-hal esensial saja dalam proses pembelajaran, selanjutkan siswa mencari tahu sendiri, dilanjutkan dengan pekerjaan rumah setiap hari. Hal ini menimbulkan gegar komunikasi antara siswa dengan guru. Guru merasa cukup dengan poin-poin penting maka materi pelajaran sudah tersampaikan, siswa merasa bahwa guru tidak cukup memberikan materi yang dapat dimengerti siswa. Kondisi inilah sebenarnya yang menjadi penyebab menurunnya prestasi belajar siswa, begitu pula siswa-siswi pada
SMP Negeri di Kecamatan Ilir Timur II Palembang.

Dalam hal kepemimpinan guru, siswa merasa bahwa guru telah cukup menjadi pemimpin yang baik dalam proses pembelajaran. Namun karena siswa di kelas sering ditinggal oleh guru, dengan alasan memberikan kemandirian kepada siswa untuk belajar sendiri, ataupun karena harus mengikuti pelatihan Kurikulum 2103, juga karena hanya diajar oleh mahasiswa magang, maka siswa beranggapan bahwa tanpa adanya guru dikelaspun siswa dapat belajar sendiri, yang mana hal ini berpengaruh terhadap prestasi belajar siswa secara keseluruhan.

Secara teoritis, seperti yang diungkapkan oleh Winkel (2009: 131), prestasi belajar siswa dipengaruhi oleh faktor internal dan eksternal. Faktor internal meliputi intelegensia, bakat, minat, dan motivasi, sedangkan faktor eksternal meliputi faktor keluarga, sekolah, dan masyarakat.

Oleh karena itu, alangkah baiknya Pemerintah (dalam hal ini Kementerian Pendidikan dan Kebudayaan) yang saat ini sudah terkonsentrasi hanya menangani masalah Pendidikan Dasar dan Menengah, dalam merancang kurikulum harus mengacu ke teori-teori yang sudah ditemukan oleh beberapa ahli, seperti teori yang ditemukan oleh Winkel di atas.

Jadi dalam merancang kurikulum harus memperhati-kan tingkat intelegensia, bakat, minat, dan motivasi siswa. Sehingga tema pelajaran yang ada dalam kurikulum tersebut nantinya, akan mudah dipahami dan dicerna oleh siswa, yang pada gilirannya dapat meningkat-kan prestasi belajar siswa, khususnya siswa pada SMP Negeri di Kecamatan Ilir Timur II Palembang. Selain itu kurikulum yang akan dirancang tersebut juga harus melibatkan faktor eksternal, bukan hanya pada guru saja, namun juga sekolah, keluarga dan masyarakat. 


\section{2) Pengaruh Kreatifitas Guru terhadap Prestasi Belajar Siswa pada SMP Negeri di Kecamatan Ilir Timur II Palembang}

Hasil pengujian regresi berganda, kontribusi kreatifitas guru terhadap prestasi belajar siswa pada SMP Negeri di Kecamatan Ilir Timur I Palembang cukup besar, yaitu $57,4 \%$, namun sayangnya pada saat diuji dengan hipotesis $t$, ternyata pengaruh sebesar itu tidak signifikan. Hal ini menggambarkan bahwa walaupun dalam penelitian ini, kreatifitas guru memberikan kontribusi yang terbesar jika dibandingkan dengan kedua variabel lainnya, namun tidak serta merta dapat meningkatkan prestasi belajar siswa, hal ini berarti pula bahwa masih banyak faktor yang dapat mempengaruhi prestasi belajar siswa.

Seperti yang sudah penulis ungkapkan pada bagian sebelumnya bahwa kurikulum yang baru diterapkan, yaitu Kurikulum 2013, belum benar-benar dipahami oleh guru, bukan hanya pada pada SMP Negeri di Kecamatan Ilir Timur II Palembang saja, namun di seluruh Indonesia. Karena ketidakpahaman inilah yang mengakibatkan kreativitas yang diciptakan oleh guru, belum memiliki arah yang jelas, sehingga bukan saja siswa yang bingung dalam menyerap tema pelajaran, namun guru juga linglung dalam mengajar.

Pada hakikatnya, mengajar jika dilakukan dengan baik telah dikatakan kreatif. Kunci keberhasilan pengembangan kreatif itu terletak pada mengajar dengan kreatif dan efisien dalam interaksi yang kondusif. Hal ini tidaklah mudah dan bukan hanya dibutuhkan keahlian dan kreatifitas dalam kegiatan pembelajaran agar tercapai apa yang diharapkan, namun terlebih dahulu guru harus memahami dan menguasai apa yang akan disampaikannya kepada siswa. Jika guru tidak paham dengan apa yang akan disampaikannya, walaupun guru menyampaikan-nya secara kreatif, tetap saja siswa tidak mampu menyerap tema pelajaran yang disampaikan oleh guru tersebut.
Walaupun banyak hal yang dapat dilakukan oleh guru dalam memacu kreatifitasnya antara lain aktif membaca, gemar berapresiasi, mencintai seni, respek terhadap perkembangan, menghasilkan sejumlah karya dan dapat memberi contoh dari hal-hal yang dituntut siswa, namun jika belum memahami tema pelajaran yang akan disampaikannya, tentulah kreatifitas tersebut jadi tidak berarti. Hal ini bukan semata-mata tanggung-jawab guru saja, namun Kementerian Pendidikan dan Kebudayaan juga harus bertanggungjawab, bukan hanya menyiapkan kurikulum saja, namun juga harus menyiapkan infrastrukturnya dan sekaligus kesiapan guru dalam memahami dan menguasai tema pelajaran yang ada di dalam kurikulum tersebut.

\section{3) Pengaruh Komunikasi Guru terhadap Prestasi Belajar Siswa pada SMP Negeri di Kecamatan Ilir Timur II Palembang}

Hasil uji regresi berganda, diperoleh hasil bahwa komunikasi memberikan kontribusi yang kecil terhadap prestasi belajar siswa, yaitu sebesar 16,6\%.. Sedangkan berdasarkan uji hipotesis t, diperoleh hasil bahwa komunikasi tidak memberikan pengaruh yang signifikan terhadap prestasi belajar siswa pada SMP Negeri di Kecamatan Ilir Timur II Palembang.

Kondisi ini menggambarkan bahwa komunikasi yang dibangun di lingkungan SMP Negeri di Kecamatan Ilir Timur II Palembang, belum memberikan kontribusi terhadap prestasi belajar siswa. Hal ini juga menggambarkan bahwa komunikasi yang terjalin di lingkungan SMP Negeri di Kecamatan Ilir Timur II Palembang ini belum berjalan baik, terutama komunikasi yang bersifat vertikal, yaitu komunikasi yang terjalin antara guru dan siswa. Sedangkan komunikasi horizontal antara guru dengan guru tidak menjadi pokok pembahasan dalam penelitian ini.

Masalah komunikasi, terutama komunikasi vertikal antara guru dengan 
siswa, bukanlah semata-mata masalah yang dihadapi oleh SMP Negeri di Kecamatan Ilir Timur II Palembang saja, kondisi ini juga sering dihadapi organisasiorganisasi lain, karena ternyata komunikasi vertikal ini terkesan mudah jika dipandang secara teoritis, namun prakteknya sulit untuk diterapkan, karena dipengaruhi oleh banyak faktor, misalnya kesibukan guru-guru tersebut, sehingga mereka tidak punya waktu yang cukup untuk berkomunikasi dengan siswanya.

Guru sibuk dengan pelatihan-pelatihan Kurikulum 2013, jarang berinteraksi dengan siswa dalam kegiatan yang bersifat ekstra kurikuler, yang terjadi hanyalah kegiatan-kegiatan yang bersifat formal, akhirnya sering tidak terjalin komunikasi yang baik antar sesama guru dengan siswa.

Berkaitan dengan penelitian yang penulis lakukan, bahwa ternyata komunikasi, terutama komunikasi yang bersifat vertikal antara guru dengan siswa tidak memberikan pengaruh yang signifikan terhadap prestasi belajar siswa pada SMP Negeri di Kecamatan Ilir Timur II Palembang.

Seperti yang telah peneliti kupas pada bagian sebelumnya, bahwa ternyata kesalahannya bukan terletak pada pola komunikasi guru, terutama komunikasi vertikal antara guru dengan siswa, namun terletak pada pemahaman guru terhadap tema pelajaran pada Kurikulum 2013 yang masih kurang. Kurikulum 2013 menitik beratkan peran aktif siswa dalam pembelajaran. Proses pembelajaran yang sesuai dengan tema pada masing-masing pelajaran, dihubungkan dengan kondisi nyata siswa, berpusat pada siswa, dan siswa dituntut aktif dalam pembelajaran. Sehinggahal ini menyebabkan guru menyerahkan proses pembelajaran kepada siswa, guru bertindak sebagai motivator, hanya mengupas sedikit tentang tema pembelajaran, selanjutkan diserahkan kepada siswa untuk mencari tahu, menganalisa, menjadi siswa aktif mengerjakan pekerjaan rumah setiap hari. $\mathrm{Hal}$ ini menyebabkan siswa merasa komunikasi yang dijalankan di kelas adalah komunikasi yang bersifat perintah dan bukan hubungan saling berbagi ilmu antara guru dengan murid.

Dalam proses pembelajaran, komunikasi vertikal pada kurikulum 2013 juga menekankan pentingnya penggunakan alat bantu komputer, dan lebih baik lagi bila siswa memiliki pengetahuan dalam mengakses internet guna menunjang pelaksanaan pembelajaran tematik pada Kurikulum 2013. Pada pelaksanaanya guru bisa dibilang jarang menggunakan Teknologi Komputer, apalagi internet dalam proses pembelajaran, sehingga siswa melihat bahwa guru tidak memiliki kemampuan meggunakan komputer maupun mengakses internet untuk menunjang proses pembelajaran tematik pada Kurikulum 2013.

\section{4) Pengaruh Kepemimpinan Guru terhadap Prestasi Belajar Siswa pada SMP Negeri di Kecamatan Ilir Timur II Palembang}

Berdasarkan hasil uji regresi berganda, diperoleh hasil bahwa kepemimpinan guru menberikan kontribusi sebesar 5,3\%. Penelitian ini menggambarkan bahwa kepemimpinan guru tidak memberikan pengaruh yang signifikan terhadap prestasi belajar siswa pada SMP Negeri di Kecamatan Ilir Timur II Palembang. Hal ini menggambarkan bahwa kepemimpinan yang diterapkan oleh guru terhadap siswa-siswinya tidak serta-merta dapat meningkatkan prestasi belajar siswa-siswinya.

Berdasarkan hasil temuan peneliti secara empiris membuktikan bahwa yang menjadi penyebab mengapa kepemimpinan guru pada SMP Negeri di Kecamatan Ilir Timur II Palembang tidak memberikan pengaruh yang signifikan terhadap prestasi belajar siswa, dikarenakan guru-guru tersebut kurang percaya diri dalam mengajar, hal ini disebabkan karena guru tersebut belum menguasai proses pembelajaran dengan Kurikulum 2013. 
Wajar saja jika guru kurang percaya diri dalam mengajar, karena guru tersebut tidak menguasai apa yang akan disampaikannya. Guru merasa bahwa proses pembelajaran terfokus pada siswa, sehingga siswa menjadi pihak yang aktif dalam proses pembelajaran. Pada kondisi ini, tidak sedikit guru yang hanya sebentar masuk ke kelas, lalu kelasnya dtinggal. Atau kelas diserahkan kepada anak kuliah (PKL) yang sedang magang di sekolah tersebut. Dimana siswa merasa tidak ada faktor pemimpin di kelas, yang mana seharusnya kelas tidak ditinggal terlalu lama dengan mahasiswa yang notabene bukan guru di sekolah tersebut.

Untuk meningkatkan kepemimpinan guru di kelas, guru tidak harus direpotkan untuk mengajar dengan pola yang cobacoba (trial and error), sehingga dapat mengembalikan rasa percaya diri guru dan mengurangi potensi kelas sering ditinggal oleh guru, dan jam mengajar mahasiswa PKL tidak seperti jam mengajar guru wali kelas. Sehingga diharapkan siswa merasa dipimpin secara baik oleh gurunya, yang pada gilirannya dapat membangun motivasi dalam diri siswa untuk mencapai prestasi belajar yang lebih baik.

Namun begitu, guru tetap harus mempersiapkan diri untuk menghadapi Kurikulum 2013, jika suatu saat kurikulum tersebut sudah dianggap siap untuk diterapkan kembali. Guru masih memiliki waktu yang cukup panjang untuk memahami dan menguasai tema pelajaran pada Kurikulum 2013 tersebut.

Kembali ke masalah kepemimpinan guru, sebenarnya kepemimpinan guru ini merupakan hal yang menjadi perhatian pokok bagi dunia pendidikan, seperti yang diungkapkan oleh beberapa ahli pendidikan, yang mengatakan bahwa kepemimpinan guru sangat mempengaruhi keberhasilan dalam proses belajarmengajar, dan sekaligus dapat meningkatkan keaktifan belajar anak didik.

Menjadi seorang pemimpin, apalagi di dalam kelas tidak perlu menunjukkan kekuasaan secara berlebihan kepada para anak didik dalam upaya mengarahkan mereka untuk mencapai tujuan-tujuan pendidikan secara cepat dan efisien, dengan tidak mengabaikan efektivitasnya. Pemimpin di kelas hendaklah memberi teladan, membangun semangat dan menanamkan pengaruh yang baik, supaya anak didik memiliki perilaku yang baik seperti yang ditetapkan dalam tujuantujuan pendidikan.

Adapun bila yang terjadi di dalam kelas siswa-siswi mengobrol di belakang ketika guru ada di dalam kelas, tidak berarti bahwa siswa-siswi tersebut salah seratus persen. Terdapat beberapa kemungkinan yang harus diperbaiki dalam performa mengajar guru, misalnya: kontak mata tidak menyeluruh, gaya mengajarnya tidak menarik, atau siswa merasa tanpa adanya guru pun siswa tetap harus aktif sendiri, mencari tahu tentang materi pembelajaran sendiri, atau beberapa hal lain yang bersifat teknis maupun non teknis. Oleh karenanya guru seyogyanya melakukan refleksi/introspeksi atas apa yang sudah dilakukan di dalam kelas sambil berupaya memberikan perbaikan atau peningkatan.

Untuk dapat tampil dengan penuh percaya diri, selain harus memahami tema pelajaran yang diajarkannya, guru juga hendaklah melakukan perencanaanperencanaan yang matang untuk pelaksanaan proses belajar mengajar termasuk evaluasinya. Ketika perencanaan ini juga, seorang guru dapat membayangkan kira-kira metode apa atau gaya kepemimpinan bagaimana yang tepat diterapkan pada situasi dan kondisi kelasnya.

Bersikap ramah ketika mengajar di dalam kelas dapat menciptakan rasa aman di kalangan siswa-siswi. Jika anak didik merasa aman dan tenang, pembelajaran dapat dilaksanakan secara ringan, mudah dan menyenangkan. Dalam kondisi seperti ini sangat dimungkinkan sikap positif anak didik baik terhadap guru maupun pelajarannya dapat timbul. Kondisi ini 
pada gilirannya dapat mendorong anak didik untuk belajar lebih baik lagi.

\section{IMPLIKASI PENELITIAN}

1. Penelitian ini mendukung dihentikannya penerapan Kurikulum 2013 secara menyeluruh terhadap seluruh siswa di seluruh sekolah, dikarenakan pola pembelajaran yang hakekatnya berpusat kepada siswa, dengan guru yang handal sebagai kunci utama diterapkannya Kurikulum 2013 tersebut. Guru mengalami kesulitan dalam menterjemahkan pembelajaran secara saintifik untuk pelajaran tematik, siswa yang tidak memiliki kecerdasan diatas rata-rata mengalami kerepotan dalam mencari sumber pembelajaran, apalagi bila tidak didukung oleh Teknologi (Internet) yang ada.

2. Guru SMP Negeri di Kecamatan Ilir Timur II Palembang dituntut harus memiliki kreativitas di dalam mengajar, dengan terlebih dahulu memahami tema pelajaran yang akan disampaikannya, bagaimana menghubungan tema pelajaran dengan kondisi nyata siswa sesuai dengan Kurikulum 2013. Dihentikannya Kurikulum 2013 untuk sekolah yang baru melaksanakannya dalam 1 semester, atau tetap dengan Kurikulum 2013 untuk sekolah percontohan, diharapkan kreatifitas guru akan kembali seperti semula, sembari mempersiapkan diri untuk membangun kreatifitas baru untukmenyongsong Kurikulum 2013.

3. Komunikasi vertikal antara guru dengan siswa sangat penting. Guru SMP Negeri di Kecamatan Ilir Timur II Palembang dituntut mampu mengkomunikasikan tema pembelajaran,sehingga meningkatkan partisipasi aktif siswa di dalam kelas. Pada hakekatnya kurikulum 2013 adalah pembelajaran berpusat pada siswa, dimana siswa mencari pengetahuan, bukan menerima
pengetahuan.Diharapkan guru kembali mampu berkomunikasi baik dengan siswanya. Jika Guru kurang mampu berkomunikasi dengan baik kepada siswanya, tentu akan terjadi miskomunikasi, sehingga siswa tidak akan mengerti apa yang disampaikan oleh gurunya dan tujuan pembelajaran tidak akan tercapai.

4. Kepemimpinan guru juga tidak kalah pentingnya dibandingkan dengan kreativitas dan komunikasi guru, Guru yang mampu memimpin siswanya dengan baik, memberikan contoh disiplin yang baik, menjalin hubungan yang baik, akan lebih mudah untuk mengarahkan siswanya, serta akan lebih mudah untuk meningkatkan minat belajar siswa, selain itu siswa juga akan segan dengan gurunya, sehingga apa yang diperintahkan oleh gurunya, akan diikuti dengan sukarela oleh siswa, termasuklah dalam hal ini perintah guru agar siswa-siswinya belajar dengan baik, hal tersebut tentu akan diikuti oleh siswa-siswinya, dengan begitu diharapkan dapat meningkatkan prestasi belajar siswa.

\section{SIMPULAN DAN REKOMENDASI}

\section{Simpulan}

Penerapan Kurikulum 2013 baik secara bersama-samamaupun secara parsial tidak ada pengaruh yang signifikan Kreatifitas, Komunikasi, dan Kepemimpinan Guru terhadap Prestasi Belajar Siswa pada SMP Negeri di Kecamatan Ilir Timur II Palembang.

\section{Rekomendasi}

1). Sebaiknya Kementerian Pendidikan dan Kebudayaan merancang kurikulum harus memperhatikan tingkat intelegensia, bakat, minat, dan motivasi siswa. Sehingga tema pelajaran yang ada dalam kurikulum tersebut nantinya, akan mudah dipahami dan dicerna oleh siswa, yang pada gilirannya dapat meningkat-kan prestasi belajar siswa, khususnya 
siswa pada SMP Negeri di Kecamatan Ilir Timur II Palembang. Kurikulum 2013 juga menekankan pada kesiapan guru sebagai kunci terlaksananya kurikulum 2013. Selain itu kurikulum yang akan dirancang tersebut juga harus melibatkan faktor eksternal, bukan hanya pada guru saja, namun juga sekolah, keluarga dan masyarakat.

2). Untuk meningkatkan daya kreatifitasnya, Guru pada SMP Negeri di Kecamatan Ilir Timur II Palembang, antara lain dengan aktif membaca, gemar berapresiasi, mencintai seni, respek terhadap perkembangan, menghasilkan sejumlah karya dan dapat memberi contoh dari hal-hal yang dituntut siswa. Guru terlebih dahulu harus memahami tema pelajaran yang akan disampaikannya. Namun hal ini bukan semata-mata tanggung-jawab guru saja, Kementerian Pendidikan dan Kebudayaan juga harus bertanggungjawab, bukan hanya menyiapkan kurikulum saja, namun juga harus menyiapkan infrastrukturnya dan sekaligus kesiapan guru dalam memahami dan menguasai tema pelajaran yang ada di dalam kurikulum tersebut, memberikan pelatihan yang intensif supaya pada saat diterapkan Kurikulum 2013 seluruh guru telah siap dalam pelaksanaannya. Guru harus diberikan pelatihan secara komprehensif, bukan hanya sekedar penataran. Guru yang mendapatkan pelatihan Kurikulum 2013 harus menjalani praktik atau dimagangkan mengajar Kurikulum 2013 di sekolah yang menjadi sekolah percontohan Kurikulum 2013. Bila dianggap sudah memiliki kemampuan yang memadai dalam pemahaman penerapan Kurikulum 2013 guru dapat dikembalikan ke sekolahnya untuk mengajar dengan Kurikulum 2013.

3). Ketidaksiapan guru dalam memahami dan kurang menguasai tema pelajaran yang ada pada Kurikulum 2013, yang mengakibatkan komunikasinya, terutama komunikasi vertikal antara guru dengan siswa tidak berjalan sebagaimana mestinya. Proses pembelajaran yang berfokus kepada siswa menjadikan siswa merasa hanya dengan mengerjakan tugas dan pekerjaan rumah maka komunikasi yang dijalankan dikelas bukanlah hal yang mutlak diperlukan. Seharusnya guru bukan saja menerangkan inti dari setiap tema pelajaran, namun juga menanyakan kepada siswa apakah pelajaran telah dimengerti, apakah memang sesuai dengan kondisi seharihari, dan pekerjaan rumah yang diberikan harus didiskusikan keesokan harinya pada mata pelajaran yang sama, sehingga siswa merasa bahwa guru memberikan perhatian penuh terhadap siswa.

4). Kepemimpinan Guru di kelas, sebaiknya guru-guru pada SMP Negeri di Kecamatan Ilir Timur II Palembang, memiliki kemampuan di dalam memimpin siswa-siswinya, terutama di dalam kelas pada saat memberikan mata pelajarannya. Guru harus disiplin, fokus pada siswa, sehingga guru dapat menjadi pemimpin di kelasnya. Mahasiswa magang diberikan jam mengajar dengan waktu yang tidak sebanyak guru wali murid, dimana siswa tidak merasa ditinggal oleh gurunya, sehingga siswa akan memiliki rasa hormat terhadap guru yang memimpin kelasnya.

\section{DAFTAR PUSTAKA}

Ahmadi, Abu. 2010. Strategi Pembelajaran.Penerbit Pustaka Setia.Bandung.

Dwi Fatmawati. 2012. Pengaruh Kreatifitas Guru dan Kelengkapan Fasilitas terhadap 
Prestasi Belajar Ekonomi siswa Kelas XI IPS SMA DU I Jombang. Tesis. Dipublikasikan. Universitas Islam Negeri Maulana Malik Ibahim, http://lib.uin-malang.ac.id/

Idochi,Moch.Anwar.2010.Kepemimpinan

Dalam Proses Pembelajaran.

Penerbit Angkasa. Bandung

Mangkunegara, Anwar Prabu. 2010. Manajemen Sumber daya Manusia Perusahaan. PenerbitPT. Remaja Rosdakarya. Bandung.

Marimin dan Dian Ratna Sari. 2006. Pengaruh Kepemimpinan dan Kemampuan Berkomunikasi Terhadap Motivasi Belajar Mata Pelajaran Ekonomi. Jurnal Ekonomi dan Manajemen "Dinamika". Dipublikasikan. Jurusan Manajemen Fakultas Ekonomi Universitas Negeri Semarang. p. 57-82.

Nazir, M. 2010. Metode Penelitian. Penerbit PT. Ghalia Indonesia. Jakarta.

PeraturanPemerintah Nomor 19 Tahun 2005 tentang Standar Nasional Pendidikan

Peraturan Menteri Pendidikan dan Kebudayaan Nomor 68Tahun 2013 tentang Kerangka Dasar dan Struktur Kurikulum Sekolah Menengah Pertama/Madrasah Tsanawiyah

Purbakawaca,Sugarda. 2009.Ensiklopedi Pendidikan. Penerbit PT. Gramedia Pustaka Utama. Jakarta.

Ruky, Ahmad S. 2010. Sistem Manajemen Kinerja. Penerbit PT. Gramedia Pustaka Tama. Jakarta.

Septi Widiyantari. 2011. Pengaruh Kreativitas Mengajar Guru Dan Disiplin Belajar Siswa Terhadap Prestasi Belajar Akuntansi. Kajian Pendidikan Akuntansi Indonesia (ejournal). Vol 1 No 2. Universitas
Negeri

Yogyakarta. http://www.journal.student.uny.ac.id/

Slameto. 2010.Belajar dan Faktor yang Mempengaruhinya.Penerbit Rineka Cipta. Jakarta

Soekartini.2009.

Meningkatkan

Efektivitas Mengajar.Penerbit

Pustaka Jaya. Jakarta.

Sugiyono, 2010. Metode Penelitian Bisnis. Penerbit: Alfabeta. Bandung

Surya, M. 2009. Psikologi Pembelajaran dan Pengajaran. Penerbit Yayasan Bhakti Winaya. Bandung

Toha, Miftah. 2009.Kepemimpinan dalam Manajemen: Suatu Pendekatan Perilaku. Cetakan ke4. Penerbit PT. Rajawali Pers. Jakarta

Utami Munandar.2012. Kreatifitas dan Keberbakatan Strategi Mewujudkan Potensi Kreatif dan Bakat.Penerbit PT. Gramedia Pustaka Indonesia. Jakarta

Winkel, W.S. 2008. Bimbingan dan Penyuluhan di Sekolah. Penerbit PT. Gramedia Pustaka Indonesia. Jakarta. 